\title{
ДЕРЖАВНА ПОЛІТИКА ДЕТІНІЗАЦІЇ ЕКОНОМІКИ: ПОДАТКОВИЙ АСПЕКТ
}

\author{
Славкова Олена Павлівна \\ доктор економічних наук, професор \\ Сумський національний аграрний університет (м.Суми, Україна) \\ ORCID: 0000-0002-1864-0810 \\ olena.slavkova.snau@gmail.com \\ Гордієнко Микола Іванович \\ кандидат економічних наук, професор \\ Сумський національний аграрний університет (м.Суми, Україна) \\ ORCID: 0000-0003-0686-9797 \\ migsumy1963@ukr.net
}

\begin{abstract}
Однією зі складових суспільного розвитку держави є стабільність економічної системи, а негативні прояви, які несе в собі тіньова економіка зумовлюють дестабілізацію та знижують авторитет органів влади, що створює додаткові перешкоди на шляху до сталого розвитку. В статті зроблено огляд характерних ознак тіньової економіки в Україні. Систематизовано чинники появи та поширення тіньової діяльності й тіньових процесів, відображено деструктивний вплив тіньового сектора економіки на фінансово-економічну сфреру.

Зроблено висновок щодо необхідності розробки ефективної політики детінізації національної економіки та комплексної програми заходів, які необхідно реалізувати. Детінізація економіки повинна охоплювати в першу чергу питання оподаткуванням. Акцентується увага на необхідність удосконалення системи адміністрування податків.

На основі системного аналізу причин тінізаиії економіки зроблено висновок про необхідність розробки комплексу взаємопов'язаних заходів, спрямованих на створення сприятливих умов для легальної господарської діяльності, запровадження яких значно покращить соціально-економічний стан країни.

В статті охарактеризовано роль детінізації у створенні сприятливих умов для економічного розвитку. Визначено напрями державного регулювання у сфрері оподаткування, які необхідні для детінізації економіки за рахунок покращення системи адміністрування податків. Конкретизовано заходи, які необхідно реалізувати з метою детінізації національної економіки.
\end{abstract}

Ключові слова: детінізація, державне управління, тіньова економіка, оподаткування, адміністрування податків.

DOI: https://doi.org/10.32845/bsnau.2019.3.1

Постановка проблеми у загальному вигляді. Численні фінансові проблеми в економіці України негативно впливають на макроекономічні показники країни, гальмують соціально-економічні реформи та перешкоджають розвитку, стабільності через існування тіньової економіки та розширення тіньової активності. Зменшення обсягу тіньових зв'язків та економічних процесів $є$ важливою частиною стратегії реформ. Виходячи з цього дослідження явища тіньової економіки, її основних аспектів та її функціонування, з метою формування дієвих пропозицій, $є$ важливим завданням для державного управління в умовах сьогодення.

Питання детінізації економіки постійно знаходиться в полі зору багатьох вітчизняних та зарубіжних науковців і на сьогодні представлено широким спектром наукових досліджень. Серед основних можна виділити таких як: Р.Р. Августін (Августин Р.Р., 2014), А. В. Базилюк (Базилюк А. В. Волик В. Ф., 1997), Є. Борщук (Борщук $Є$. ., Ліпенцев А., Заверюха М.,2015), А.Бочі (Бочі А., Поворозник В., 2014), 3.С. Варналій (Варналій 3.С., 2009), О.О.Леонова (Леонова О.О., 2018), І.Мазур (Мазур І., 2005), М.М. Миколайчук (Миколайчук М.М., 2017), В.В. Сандугей (Сандугей В.В., 2017), Л.В.Шинкарук (Шинкарук Л.В., 2015) та інші.

Аналізуючи дослідження даної проблеми у вітчизняній науці можемо сказати, що незважаючи на достатньо велику кількість науковців існують ще питання, які не були досліджені.

Серед вітчизняних дослідників адміністрування пода-

тків можна виділити наступних: Л.М. Алексеєнко (Алексеєнко Л.М., 2003), І.П. Житню (Житня І.П., 2010), К.П. Проскуру (Проскура К.П., 2014), А.О. Селіванова (Селіванов А.О., 2002), В.П. Хомутенка (Хомутенко В.П., 2015) та інші.

Але на даний час питання детінізації економіки шляхом покращення методів та механізмів адміністрування податків залишаються недостатньо вивченими.

Формування цілей статті. Метою даного дослідження є аналіз ситуації та розробка рекомендацій щодо вдосконалення механізмів державного регулювання у сфері детінізації економічних відносин в Україні на основі податкового адміністрування.

Методи дослідження. У дослідженні були використані такі методи, як діалектичний - при формуванні етапів розвитку тіньової економіки в Україні та світі; систематизації та узагальнення - при аналізі нормативних документів та теоретичних джерел; системний - при дослідженні оцінки рівня тіньової економіки та аналізі діяльності різноманітних структур щодо детінізації; абстрактно-логічного методу - для визначення пріоритетних напрямів державного регулювання щодо розробки пропозицій з детінізації економіки;

Результати дослідження. Питання детінізації економіки виникає в багатьох країнах світу, особливо в країнах з тіньовою економікою де така проблема може набути масштабності та стати серйозною перешкодою розвитку держави. Тіньовий сектор може мати зв'язки з легальним сектором економіки та негативно впливати на всі ссрери суспільного життя, 
економіку країни, політичний устрій, систему управління, соціальну сфреру та міжнародні зв'язки.

Невтручання в дану сферу може привести до фатальних помилок у визначенні пріоритетів розвитку макроекономічних показників, до фінансово-економічних диспропорцій, що веде до викривлення загальної політики держави.

Питання детінізації досліджувалися різними вченими починаючи з 1960-1970 років, так однією з перших була праця вченого з США П. Гутмана та мала назву «Підпільна економіка» в якій описувалася проблема детінізації та зверталася увага на неприпустимість, її масштабів і ролі (Гутман П., 1977).

Одним з перших дослідників тіньової економіки можна виділити також Е.Фейга, (Фейгом Е., 1979). Згідно з цим тлумаченням тіньова економіка - це вся економічна діяльність, яка з будь-яких причин не враховується і не потрапляє до валового національного продукту.

Аналіз думок вчених показує, що Базилюк А.В. та Волик В.Ф. вважають, що тіньова економіка виникає тоді, коли дії владних та регулюючих структур держави, окремих людей або їх груп вступають у протиріччя з об'єктивними економічними законами» (Базилюк А. В. Волик В. Ф., 1997). Т

Такі вчені як Августин Р.Р. (Августин Р.P., 2014) та Варналій 3. С. (Варналій 3.С., 2009) виділяють форми тіньової економіки, а саме: 1) неформальна економічна діяльність легальне (нерегламентоване державою) виробництво товарів і надання послуг; 2) підпільна економіка - порушення в межах дозволеної економічної діяльності; 3) незаконна економіка - здійснення заборонених видів діяльності .

Не залишилися без уваги питання формування інституційного середовища та механізму процесів легалізації тіньового сектору економіки. Так Мазур І. вказує, що при визначенні шляхів детінізації економіки передусім необхідно дослідити три базові складові: неформальну, приховану та кримінальну (Мазур, 2005). При чому, як вважає автор, до такого виду як кримінальна економіка необхідно використовувати адміністративно-правові методи впливу з метою оздоровлення економіки нашої держави.

На думку деяких вчених структура української економіки багатоаспектна, а її зміни взаємопов'язані й відображаються в різних результатах діяльності. Найбільше впливають на стан економіки такі структурні зрушення: технологічні, від яких залежить поява принципово нових технічних засобів та господарський уклад; відтворювальні, які знаходять відображення у співвідношенні сфери послуг, промислового та сільськогосподарського виробництва; просторові, які пов'язані зі зміщенням меж регіонів та економічних зон (Шинкарук Л.В., 2015; Миколайчук М.М., 2017).

Дослідження процесів тіньової економіки в Україні свідчить, що її основою $є$ недосконалість ринкових відносин, що проявляється в суперечливому та стихійному їх спрямуванні, а також завдяки можливості тіньової економіки швидше адаптуватись до реальних умов господарювання, її мобільності та невеликих витрат (Борщук $€$., Ліпенцев А., Заверуха М., 2015).

Для подолання негативних явищ Леонова О.О. пропонує проведення реформи детінізації шляхом: посилення заходів проведення антикорупційної стратегії та ринкового регулювання економіки; забезпечення ефективності податкової реформи; визначення напрямків реформи банківської системи (підвищення прозорості діяльності Національного банку України щодо рефінансування банків, гнучкого валютного курсоутворення, поширення безготівкових розрахунків та ін.); оновлення законодавчих актів регулювання ринку праці; здійснення судової реформи (зменшення корупції, підвищення професіоналізму судових та правоохоронних органів, посилення незалежності від політичних процесів, зміцнення ролі конституційного правосуддя та забезпечення прозорості та неупередженості судових процесів) (Леонова О.О., 2018).

За дослідженнями проведеними компанією Ernst \& Young за підтримки Mastercard 23,8 відсотків від офіційного ВВП України, або 846 млрд. гривень, становлять тіньові операції. 3 них: 19,7\% ВВП (702 млрд грн.) становить готівкова тіньова економіка; 4,1\% ВВП (144 млрд грн..) - домашнє виробництво товарів для власного кінцевого використання, тобто - не грошова тіньова економіка (Тіньова економіка України, 2019).

Аналізуючи даний графік ми бачимо, що детінізація української економіки стала можливою завдяки:

- продовженню позитивних економічних тенденцій і збереженню ознак загальної економічної стабілізації;

- посиленню ринкових тенденцій і поступовій оптимізації процесів формування цін на внутрішніх ринках, в тому числі внаслідок демонополізації ринків поряд з розробкою та реалізацією НБУ жорсткої монетарної політики для стримування інфляції в межі цільового діапазону;

- збереженню сприятливих умов для ведення бізнесу в Україні, що підтверджується досить високим рівнем ділової активності бізнесу та поліпшенням очікувань (Мінекономрозвитку оцінило розмір тіньової економіки України (інфрографіка), 2019).

43

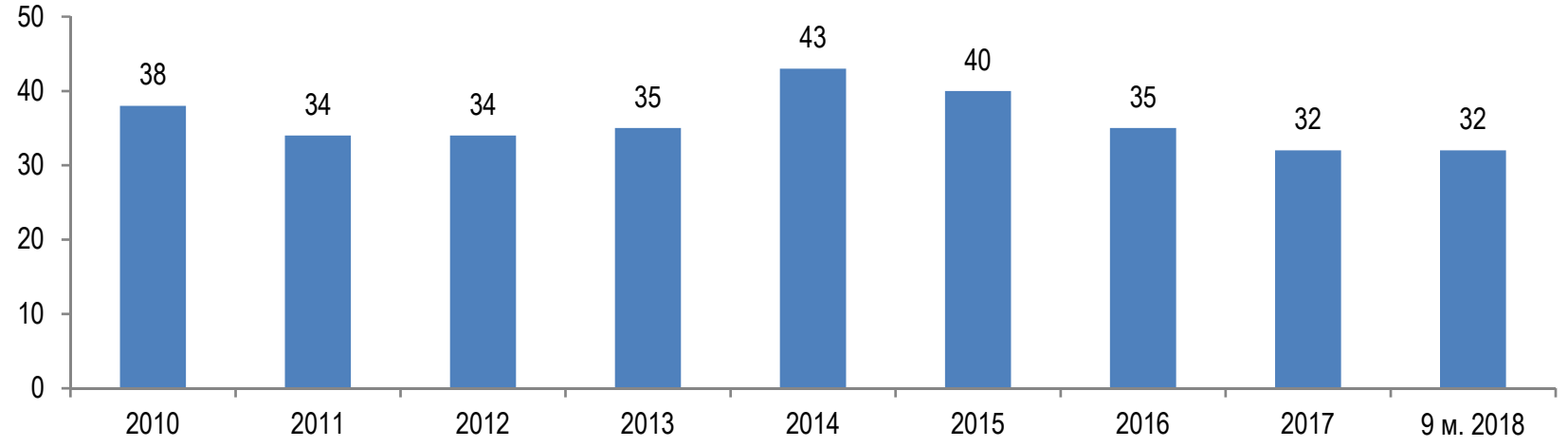

Рис.1. Рівень тіньової економіки в \% до обсягу офріційного ВВП

Джерело: Складено на основі https://news.finance.ua/ua/news/-/443755/minekonomrozvytku-otsinylo-rozmir-tinovoyi-ekonomiky-ukrayiny-infografika. 
Але на нашу думку динаміка детінізації української економіки стримується невирішеними проблемами, які негативно позначаються на розвитку економіки країни в цілому, що може бути пов'язано з наявністю непідконтрольних владі територій, утворених в ході військової агресії на Сході країни та анексією Криму.

Дослідження компанії Ernst \& Young за підтримки Mastercard в Україні свідчить також про те, що більше чверті, а саме 26,2 відсотки обсягу "готівкової тіньової економіки", що складає 5,3відсотка ВВП або 190 млрд. гривень - це "наслідкова тіньова економіка", де ініціаторами розрахунку готівкою $€$ обидві стороні - і продавець, і покупець. А решта 73,8 відсотка загального обсягу української тіньової економіки або 14,4\% ВВП - 512 млрд грн. - це "пасивна тіньова економіка", ініціатором якої $є$ продавець. Стимулювання безготівкових електронних розрахунків має суттєво зменшити саме рівень "пасивної тіньової економіки" (Тіньова економіка України, 2019).

Детінізація української економіки є пріоритетним і принципово важливим напрямком сучасної економічної політики України. У той же час багатовимірність і розгалуження проявів детінізації свідчать тільки про марність не системних та репресивних проявів боротьби з нею. Це пов'язано з тим, що в українській економіці притаманні такі явища, як: дорожнеча і низька прибутковість ведення бізнесу, обтяжлива податкова система, в якій фіскальна функція грає вирішальну роль, звуження внутрішнього ринку та нерозвиненість ринкових регуляторів для визначення ціни ресурсів і фракторів конкурентоспроможності, нездатність держави забезпечити прозорі умови діяльності і гармонізувати економічні інтереси господарюючих суб'єктів (Сандугей В.В., 2017).

До основних інструментів тінізації фінансових потоків відносять мінімізацію податкових зобов'язань, ухилення від оподаткування, виведення коштів за межі України, легалізацію доходів, одержаних злочинним шляхом, та порушення бюджетних видатків (Бочі А., Поворозник В., 2014).

В цьому напрямку ми вбачаємо, що стимулювання процесів детінізації буде сприяти організація прозорої системи адміністрування податків в Україні. Це питання нове та потребує відповідного дослідження як в історичному аспекті, так і з урахуванням сучасних умов і основ формування та реалізації податкової політики. Потребу в розробці методологічних засад державної політики у сфері адміністрування податків значною мірою зумовлено невизначеністю відповідних понять, принципів і підходів до вивчення зазначеної проблеми, що вказує на необхідність проведення наукових досліджень.

У перекладі з латинської мови «administrate» означає керувати за допомогою наказів, бюрократично, не враховуючи думки про сутність справи. Вітчизняні словники «адміністрування» трактують як: управління, керування, завідування; організаційно-розпорядча діяльність менеджерів й організаторів управління (Алексеєнко Л. М., 2003; Нечволод Л. І., 2009).

Існують різні види адміністрування у фінансовій, правовій та економічній сфрерах. Слушну думку з цього приводу висловили І. П. Житня і В.О. Корецька-Гармаш, які відзначають, що термін «адміністрування» у наш час трактується науковцями переважно з позицій потреб тих галузей, які вони досліджують (Житня І. П., Корецька - Гармаш В. О., 2010).

Зокрема, Селіванов А.О. розглядає адміністрування податків як «...правовідносини, що складаються у сфері здійснення уповноваженими державними органами заходів з погашення податкового боргу і передбачають застосування методів владно-примусового характеру до платників податків» (Селіванов А. О., 2002, с. 35). Таке специфічне розуміння адміністрування податків зумовлено тим, що вчений розглядає тільки юридичний аспект оподаткування.

Тобто науковець обґрунтовує так зване «вузьке» розуміння категорії, яка досліджується (по суті в значенні діяльності з примусового стягнення не своєчасно чи не в повному обсязі сплачених податків і зборів) (Хомутенко В.П., Луценко І.С., Хомутенко А.В., 2015). Адміністрування податків і зборів у значенні будь-якої (як позитивної управлінської, так і юрисдикційної) фріскальної діяльності відповідних органів виконавчої влади розглядає профессор В. М. Мельник. Він зазначає, що «адміністрування податків - це управлінська діяльність органів державної виконавчої влади, яка пов'язана з організацією процесу оподаткування, засновується на державних законодавчих і нормативних актах та використовує соціально зумовлені і сприйняті акти» (Мельник В. М., 2007).

Проскура К. П. дає власне визначення податкового адміністрування, на його думку, це нормативно регламентована організаційно-розпорядча діяльність повноважних державних органів у сфрері управління процесами оподаткування з метою забезпечення виконання вимог податкового законодавства учасниками податкових відносин (Проскура К. П., 2014)

Окремі вчені вважають, що адміністрування - це наука, яка формулює принципи ефективного управління податковою системою в даних соціально-економічних умовах і суспільно-політичних обставинах, оцінює податкову систему в світлі певних теоретичних критеріїв.

Ми погоджуємося з думкою Савчук В. А., що процес адміністрування податків повинен ґрунтуватись на наукових принципах, повинен мати відповідне обгрунтування, але наука про адміністрування, не повинна бути відірваною від самого адміністрування, як управлінської діяльності, а бути його частиною.

Термін «адміністрування» у різних відмінках досить часто зустрічається у вітчизняних нормативно-правових актах різних видів, але в кожному з них відсутнє визначення його поняття.

В Україні вперше на законодавчому рівні застосована широко вживана в сучасній економічній науці термінологія «адміністрування податків, зборів (обов'язкових платежів)», 3 прийняттям Податкового кодексу України (ПКУ).

Згідно ПКУ, адміністрування податків, зборів, митних платежів, єдиного внеску на загальнообов'язкове державне соціальне страхування (далі - єдиний внесок) та інших платежів відповідно до законодавства, контроль за дотриманням якого покладено на контролюючі органи (далі - податків, зборів, платежів) - це сукупність рішень та процедур контролюючих органів і дій їх посадових осіб, що визначають інституційну структуру податкових та митних відносин, організовують ідентифікацію, облік платників податків і платників єдиного внеску та об'єктів оподаткування, забезпечують сервісне обслуговування платників податків, організацію та контроль за сплатою податків, зборів, платежів відповідно до порядку, встановленого законом (Податковий кодекс України, 2019).

На сьогодні у наукових працях та публікаціях учених досить часто вживається термін «система адміністрування», 
який розглядається як управлінська діяльність органів державної фіскальної служби в межах, установлених чинним законодавством. Тобто, держава через відповідні органи вступає у відносини з суб'єктами господарювання з приводу сплати останніми податків і зборів.

Механізм, за допомогою якого здійснюється адміністрування податків, зборів (обов'язкових платежів) включає в себе цілі, функції, принципи, методи управління процесом справляння податків і зборів. Завдяки адмініструванню податків, достатньою мірою забезпечується дієвість та функціонування самої системи адміністрування, яка, у свою чергу $є$ складовою податкової системи держави.

За роки незалежності жодна влада України не змогла побудувати ефективної податкової системи, що погіршує розвиток бізнесу в Україні та позиції нашої держави на глобальному економічному ринку та в економічних рейтингах.

Українська податкова система - одна з найбільш громіздких і найменш ефективних у світі. Щорічно Світовий банк проводить дослідження податкових систем у всьому світі, у якому враховується кількість податкових платежів, час, необхідний на їх сплату, а також загальне податкове навантаження на середнє підприємство, що не користується податковими пільгами. У рейтингу податкового навантаження на бізнес Україна у 2015 р. зайняла 107 місце серед 189 економік, піднявшись за рік лише на одну сходинку.

Ми вважаємо, що в цілому зміни до податкового законодавства мають відповідати кільком вимогам - стимулювати розвиток економіки, а також сприяти скороченню податкового навантаження на бізнес, спрощенню адміністрування, забезпеченню прозорості, у тому числі і для розкриття «тіньових» секторів економіки.

На нашу думку, у сучасних умовах основним напрямком державної макроекономічної політики щодо системи оподаткування, у тому числі адміністрування податків, має стати впровадження заходів, спрямованих на запровадження стимулюючої функції системи оподаткування в Україні, яка дозволить підвищити ділову активність населення, значно збільшити кількість і якість платників податків. Це також вплине на зменшення тінізації економіки та створити умови для формування цивілізованих відносин між законослухняними платниками податків і фіскальною службою.

Вважаємо, що обмеження тіньових схем в економіці України можливе за умов: збільшення штрафнних санкцій за ухилення від сплати податків; запровадження більш жорстких методів кримінальної відповідальності посадових осіб відповідальних за сплату податків, розширення повноважень контролюючих органів щодо здійснення перевірок додержання законодавства щодо сплати податків.

Висновки. Підсумовуючи вищенаведене, можна сказати, що подолання тіньової економіки є передумовою вступу України в ЄС і головною проблемою України на шляху до Європейського співтовариства, тому розробка заходів щодо її зниження є першочерговим завданням українського уряду.

Перспективи подальших досліджень будуть направлені на удосконалення механізмів та інструментів публічного регулювання стимулювання структурних змін та детінізації економіки.

\section{Список використаної літератури:}

1. Borschuk E., Lipentsev A., Zaveryukha M. (2015) Theoretical and applied foundations of the shadow economy of Ukraine. Public administration efficiency. Vip 43. 2015. pp. 29-35.

2. Alekseyenko LM (2003) Economic Explanatory Dictionary: Property, Privatization, Securities Market [Ukrainian - English Russian]. Ternopil: Aston, 2003. 672 p.

3. Zhytnya IP, Koretska - Garmash VA (2010) Administering value added tax in Ukraine: organizational directions of development. Scientific News of the University of Dal. No. 1. Available at: http://www.nbuv.gov.ua/e-journals. (Accessed 05/10/2019).

4. Selivanov AO (2002) Tax Administration: New Problems in Administrative and Financial Law of Ukraine. Law of Ukraine. 2002. № 2. pp. 34 - 38.

5. Khomutenko VP, Lutsenko IS, Khomutenko AV (2015) Administering Taxes, Fees, Payments: Teach. manual. Odessa, Atlant. $314 \mathrm{p}$. $444 \mathrm{p}$.

6. Melnyk VM (2007) Dominants of taxes and taxation and ensuring the completeness of their action: diss. AD: 08.00.08. K.,

7. Proskura KP (2014) Tax Administration in Ukraine in the Post-Crisis Period: Efficiency and Directions of Modernization: A Monograph. European University. Kyiv: Emcon LLC. 376 p.

8. Tax Code of Ukraine. Available at: http://zakon2.rada.gov.ua/laws/show/2755-17. (Accessed 05/10/2019).

9. Nechvolod LI (2009) A Modern Dictionary of Foreign Language Words. X.: Torsingplus. 768 p.

10. Sandugey VV (2017) Detinization of the domestic labor market as a prerequisite for effective European integration. Market infrastructure. Issue 3. years 11-15.

11. The Ministry of Economic Development and Industry estimated the size of the shadow economy of Ukraine (infographic) (2019). Available at: https://news.finance.ua/en/news///443755/minekonomrozvytku-otsinylo-rozmir-tinovoyi-ekonomiky-ukrayinyinfografika (Accessed 10.05.2019).

12. The shadow economy of Ukraine. Available at: https://bank.gov.ua/news/all/doslidjennya-tinovoyi-ekonomiki-v-ukrayini-mayje-chvert-vvp--abo-846-mlrd-griven--perebuvaye-v-tini ( Accessed 10/05/2019).

13. Leonova $\mathrm{OO}$ (2018). Conditions of realization of the state policy in the sphere of the shadowing of the economy of Ukraine. Actual problems of public administration. №1 (53). ages 1-6.

15. Mykolaychuk MM (2017) State regulation of the shadow economy as a motivation for the development of its technological level. Public administration: theory and practice. №2. pp. 46-56.

16. Shinkaruk L.V. (2015) Structural transformations in the economy of Ukraine: dynamics, contradictions and impact on economic development: Sciences. ext. NAS of Ukraine «Inst. and predicted. NAS of Ukraine ". Kiev. 304 p. Available at: http://ief.org.ua/docs/ en / 288.pdf. (Accessed 05/10/2019). 
17. Augustine R.R. (2014) Generalization of world experience in the formation of an effective system of shading the national economy. Scientific Bulletin of NLTU of Ukraine: collection of scientific-technical. Lviv Ave. 24.1. 192-197. Available at :: http://nbuv.gov.ua/UJRN/nvnltu_2014_24.1_35. (Accessed 05/10/2019).

18. Bochi A., Povoroznik V. (2014) The shadow economy in Ukraine: causes and ways of overcoming. International Center for Policy Studies. Available at: http://icps.com.ua/assets/uploads/files/t_novaekonom_kaukra_ni.pdf. (Accessed 05/10/2019).

19. Varnaliy Z.S. (2009) Economic security: a textbook K .: Knowledge. $64 \overline{7}$ p.

20. Mazur I. (2005) Corruption as an institute of shadow economy Economy of Ukraine. No. 8. pp. 68-75.

21. Basiluk AV Volyk VF (1997) What is a shadow economy, causes and conditions of development. Trade unions of Ukraine. No. 2. p.35-38.

22. Feige E. (1979) How big is the Irregular Economy? Challenge. Vol. 6. № 22. pp. 5-13.

Olena Slavkova, Dr, Professor, Sumy National Agrarian University (Sumy, Ukraine)

Mykola Hordiienko, PhD, Professor, Sumy National Agrarian University (Sumy, Ukraine)

State policy of unshadowing the economy: fiscal aspect

One of the components of the state's social development is the stability of the economic system; and the negative manifestations of the shadow economy cause destabilization and reduce the authority of government agencies and public bodies, which creates additional obstacles to sustainable development. The article provides an overview of the characteristic features of the shadow economy in Ukraine. The factors of appearance and spread of shadow activity and shadow processes are systematized; the destructive influence of the shadow sector of economy on the financial and economic sphere is reflected in this paper.

It has been concluded that it is necessary to develop an effective policy to unshadow the national economy and a comprehensive program of measures to be implemented. The unshadowing of the economy should primarily cover the issues of fiscal policy. Special attention has been paid to the necessity of improvement of the tax administration system.

Based on a systematic analysis of the causes of the shadow economy growth, it can therefore be concluded that it is necessary to develop a set of interrelated measures aimed at creating favorable conditions for legal economic activity, the introduction of which will significantly improve the country's socio-economic situation.

The article describes the role of de-shadowing in creating favorable conditions for economic development. The directions of state regulatory measures in the field of taxation, which are necessary for the economy unshadowing by improving the tax administration system, are determined. The measures to be implemented in order to unshadow the national economy are specified.

Key words: unshadowing, public administration, shadow economy, taxation, tax administration.

Дата надходження до редакції: 15.08.2019 р. 